\title{
Luteococcus japonicus gen. nov., sp. nov., a New Gram-Positive Coccus with LL-Diaminopimelic Acid in the Cell Wall
}

\author{
TOMOHIKO TAMURA, MARIKO TAKEUCHI, AND AKIRA YOKOTA \\ Institute for Fermentation, Osaka, Yodogawa-ku, Osaka 532, Japan
}

Received 1 November 1993/Accepted 19 January 1994

\begin{abstract}
A new gram-positive, nonmotile coccus is described. Strains IFO $12422^{\mathrm{T}}$ ( $\mathrm{T}=$ type strain) and IFO 15385 in the Institute for Fermentation, Osaka, culture collection, which were isolated from soil and water, respectively, have the following chemotaxonomic characteristics: menaquinone $\mathrm{MK}-9\left(\mathrm{H}_{4}\right) ; \mathrm{G}+\mathrm{C}$ content of DNA of $67 \mathrm{~mol} \%$; and LL-diaminopimelic acid, alanine, glycine, and glutamic acid in a molar ratio of ca. 1:2:1:1 (type A3 $\gamma$ ). Mycolic acids are not present. The taxonomic characteristics of these organisms are different from those of previously described gram-positive, high-G+C-content cocci. The partial 16S rRNA sequence indicated that IFO $12422^{\mathrm{T}}$ represents a distinct line of descent among gram-positive bacteria with a high $\mathrm{G}+\mathrm{C}$ content. The name Luteococcus japonicus gen. nov., sp. nov. is proposed. The type strain is strain IFO 12422.
\end{abstract}

Gram-positive cocci "Micrococcus aurantiacus" IFO 12422 and Micrococcus sp. IFO 15385 (equivalent to CCM 2142) were isolated in Japan from soil on Tokara island and from water for brewing "miyamizu," respectively (21), and have been maintained in the culture collections of the Institute for Fermentation, Osaka, and Czech Collection of Microorganisms. Micrococcus species contain lysine in their cell walls, but strains IFO 12422 and IFO 15385 contain LL-diaminopimelic acid (LL-DAP) instead of lysine. Therefore, the taxonomic position of these strains has remained uncertain.

The following five genera of gram-positive cocci with a high DNA guanine-plus-cytosine $(\mathrm{G}+\mathrm{C})$ content have been described previously: Micrococcus (31), Deinococcus (2), Stomatococcus (1), Kineococcus (38), and Pelczaria (25). However, gram-positive cocci with a high $\mathrm{G}+\mathrm{C}$ content and containing LL-DAP have not been known.

In this paper, we describe the characterization and classification of these gram-positive cocci and we propose that they be included in a new genus, Luteococcus, as Luteococcus japonicus, gen. nov., sp. nov.

\section{MATERIALS AND METHODS}

Bacterial strains and culture conditions. Strains IFO $12422^{\mathrm{T}}$ and IFO 15385 (equivalent to CCM 2142), which were isolated from soil on Tokara island, Japan, and from water for brewing "miyamizu" in Hyogo prefecture, Japan, respectively (21), were obtained from the Institute for Fermentation, Osaka, culture collection. For chemotaxonomic studies, these strains were grown in shake cultures (nutrient broth; Difco, Detroit, Mich.) at $28^{\circ} \mathrm{C}$, and cells were harvested in the stationary phase, washed twice with water, and then freeze-dried.

Morphological and cultural characteristics. Cell morphology was examined by using cells grown on nutrient agar (Difco). Samples for scanning with a model JSM 5400 scanning electron microscope (JEOL, Ltd., Tokyo, Japan) were prepared by dehydrating cells through a graded ethanol series and then in a Hitachi model HCP-2 critical point drying apparatus.

Observation of cells by transmission electron microscopy was performed as follows. The cells were fixed in $2.5 \%$

\footnotetext{
* Corresponding author. Mailing address: Institute for Fermentation, Osaka, 17-85, Juso-honmachi 2-chome, Yodogawa-ku, Osaka 532, Japan. Phone: 06-300-6555. Fax: 06-300-6814.
}

glutaraldehyde and $1 \% \mathrm{OsO}_{4}$, dehydrated through a graded ethanol series, and then embedded in Epon 812. Thin sections were stained with uranyl acetate and lead citrate and examined under an electron microscope, model JEM-1200EX (JEOL).

Phenotypic characterization. Unless otherwise indicated, all tests were carried out at $28^{\circ} \mathrm{C}$. Catalase activity was determined by bubbling in a $3 \%$ hydrogen peroxide solution. Oxidase activity was determined by the oxidation of $1 \%$ tetramethyl-pphenylenediamine on filter paper. Acid production from carbohydrates was studied in media containing $0.5 \%$ peptone, $0.25 \% \mathrm{NaCl}, 0.003 \%$ bromcresol purple, and each carbohydrate at a concentration of $0.5 \%(\mathrm{pH} \mathrm{7.2)}$. Nitrate reduction and hydrolysis of starch, gelatin, casein, and esculin were tested by the methods described by Cowan and Steel (9).

Chemical analyses. Preparation of peptidoglycan and analysis of amino acids, sugar, cellular fatty acids, polar lipids, mycolic acids, isoprenoid quinones, and glycolyl residues were carried out by the method described previously (38).

DNA base composition. DNA was obtained by the method of Saito and Miura (29). The G+C content of the DNA was determined by the method of Mesbah et al. (19) after treatment with $P_{1}$ nuclease and alkaline phosphatase and by highperformance liquid chromatography (HPLC) using a model LC-6AD apparatus (Shimadzu) equipped with a Cosmosil $5 \mathrm{C}_{18}$-AR column (4.6 by $150 \mathrm{~mm}$; Nacalai Tesque, Inc., Kyoto, Japan).

DNA homology experiment. DNA-DNA homology was studied by the photobiotin-microplate hybridization method of Ezaki et al. (10).

In vitro amplification of rRNA genes. DNA was used for in vitro amplification of the rRNA gene (rRNA) by the PCR technique (28) in combination with a 16S rRNA gene specific primer pair, $5^{\prime}$-AGTTTGATCCTGGCTC OH-3' (identical to positions 10 to 25 in the Escherichia coli numbering system [3]) and 5'-AAGGAGGTGATCCAGCC OH-3' (complementary to positions 1541 to 1525 ), according to the method described previously (34). The amplification was carried out with a Taq polymerase kit (The Perkin-Elmer Co.). The cycling parameters were as follows: $2.5 \mathrm{~min}$ of preheating at $95^{\circ} \mathrm{C}, 1 \mathrm{~min}$ of denaturation at $94^{\circ} \mathrm{C}, 2.5 \mathrm{~min}$ of annealing at $58^{\circ} \mathrm{C}$ and $2.5 \mathrm{~min}$ of extension at $72^{\circ} \mathrm{C}$. After 30 cycles there was a final incubation at $72^{\circ} \mathrm{C}$ for $5 \mathrm{~min}$. The length of the amplified fragment was checked by agarose gel electrophoresis $(1 \%$, wt/vol).

Sequence determination and analysis. The amplified DNA 
was purified with Suprec-01 (Takara Co., Ltd.) after electrophoresis on agarose gel $(1 \%, \mathrm{wt} / \mathrm{vol})$. The purified DNA was sequenced with a Sequenase kit for ${ }^{35}$ S-dATP (Amersham International plc) with the primers 5'-AGTTTGATCCTGGC TC OH-3' (identical to positions 10 to 25), 5'-GTGTTACT CACCCGT OH-3' (complementary to positions 123 to 109), 5'-TACGGGAGGCAGCAG-3' (identical to positions 343 to 357), 5'-CTGCTGCCTCCCGTAG OH-3' (complementary to positions 357 to 342 ), 5'-GTGCCAGCAGCCGCGG OH-3' (identical to positions 515 to 530), 5'-ACCGCGGCTGCTG GC OH-3' (complementary to positions 531 to 517), 5'-TCT ACGCATTTCACC OH-3' (complementary to positions 704 to 690), 5'-GTCAATTCCTTTGAGTTT OH-3' (complementary to positions 924 to 907 ), 5'-AGGGTTGCGCTCGTTG $\mathrm{OH}-3^{\prime}$ (complementary to positions 1115 to 1100 ), $5^{\prime}$-CCAT TGTAGCACGTGT OH-3' (complementary to positions 1242 to 1227 ), 5'-ACGGGCGGTGTGTAC OH-3' (complementary to positions 1406 to 1392 ), and 5'-GGCTACCTTGTTACGA OH-3' (complementary to positions 1510 to 1495). DNA sequences were aligned by the ODEN system (12). Nucleotide substitution rates ( $K_{\text {nuc }}$ values) were calculated (14), and the phylogenetic tree was constructed by the neighbor-joining method (30). The topology of the trees was evaluated by bootstrap analysis of the sequence data with Clustal V software (11).

Nucleotide sequence accession numbers. The sequences were aligned with published sequences from DDBJ, GenBank, and EMBL under the following accession numbers: M37200 (Aeromicrobium erythreum), M23411 (Arthrobacter globiformis), M38242 (Micrococcus luteus), X53211 (Nocardioides albus), X53189 (Nocardioides fastidiosa), X53214 (Nocardioides jensenii), X53212 (Nocardioides luteus), X53221 (Propionibacterium acidipropionici), X53218 (Propionibacterium acnes), X53217 (Propionibacterium freudenreichii), X53220 (Propionibacterium thoenii), X72377 (Sporichthya polymorpha), X61478 (Streptomyces griseus), X53215 (Terrabacter tumescens). The sequence of Nocardioides simplex was taken from reference 5, and that of Propionibacterium innocuum was taken from reference 24.

The nucleotide sequence data of $L$. japonicus will appear in the DDBJ under the accession number D21245.

\section{RESULTS AND DISCUSSION}

Morphological, physiological, and biochemical characteristics. Both strains IFO $12422^{\mathrm{T}}$ and IFO 15385 are gram-positive cocci. The cells are 0.7 to $1.0 \mu \mathrm{m}$ in diameter, occur singly as well as in pairs and in tetrads (Fig. 1), and are nonmotile. Rod-shaped or filamentous cells were not observed at any stage of growth or when IFO $12422^{\mathrm{T}}$ was cultured under different growth conditions. Observation of thin sections of the cells in the early-growth phase revealed a cross-wall septum (Fig. 2). The physiological and the biochemical characteristics of strains IFO $12422^{\mathrm{T}}$ and IFO 15385 are summarized in Table 1. On most solid media, the strains formed smooth, yellow colonies. Both strains had urease and catalase activities but no oxidase activity. They hardly utilized the organic acids studied; they were facultative anaerobes. The temperature range for growth was 12 to $38^{\circ} \mathrm{C}$, and the optimum temperature was 26 to $28^{\circ} \mathrm{C}$.

Chemotaxonomic characteristics. The cellular fatty acids of IFO $12422^{T}$ and IFO 15385 are shown in Table 2. The major cellular fatty acids of strains IFO $12422^{\mathrm{T}}$ and IFO 15385 were unsaturated, straight-chain acids $\mathrm{C}_{16: 1}, \mathrm{C}_{17: 1}$, and $\mathrm{C}_{18: 1}$. The strains also contained 2-hydroxy-iso-octadecanoic acid (2-OH iso-18:0). The major menaquinone of IFO $12422^{\mathrm{T}}$ and IFO 15385 was MK-9 $\left(\mathrm{H}_{4}\right)$ (Table 3$)$. The chemotaxonomic charac-
TABLE 1. Morphological and biochemical characteristics of L. japonicus IFO $12422^{\mathrm{T}}$ and IFO 15385

\begin{tabular}{|c|c|c|}
\hline \multirow{2}{*}{ Characteristic } & \multicolumn{2}{|c|}{ Result for strain: } \\
\hline & IFO $12422^{\mathrm{T}}$ & IFO 15385 \\
\hline Color of colony & Yellow & Yellow \\
\hline Morphology (diam) & Coccus $(0.7-1.0 \mu \mathrm{m})$ & Coccus $(0.7-1.0 \mu \mathrm{m})$ \\
\hline Motility & - & - \\
\hline $\begin{array}{l}\text { Growth on nutrient } \\
\text { agar }\end{array}$ & Moderate & Moderate \\
\hline Gram staining & + & + \\
\hline Spore formation & - & - \\
\hline \multicolumn{3}{|l|}{ Acid production from: } \\
\hline D-Ribose & + & + \\
\hline D-Xylose & - & - \\
\hline D-Arabinose & - & - \\
\hline L-Arabinose & + & + \\
\hline D-Glucose & + & + \\
\hline D-Galactose & + & + \\
\hline D-Mannose & + & + \\
\hline D-Fructose & + & + \\
\hline $\begin{array}{l}\text { L-Rhamnose } \\
\text { Sucrose }\end{array}$ & $\begin{array}{l}- \\
+\end{array}$ & $\overline{+}$ \\
\hline Maltose & + & + \\
\hline Trehalose & + & + \\
\hline Raffinose & + & + \\
\hline Glycerol & + & + \\
\hline Mannitol & + & + \\
\hline Inositol & + & + \\
\hline \multicolumn{3}{|l|}{ Assimilation of acid: } \\
\hline Acetic acid & - & - \\
\hline Lactic acid & + weak & - \\
\hline Malic acid & + weak & - \\
\hline Succinic acid & - & - \\
\hline Fumaric acid & - & - \\
\hline Citric acid & $\begin{array}{l}- \\
-\end{array}$ & - \\
\hline Formic acid & $\begin{array}{l}- \\
-\end{array}$ & - \\
\hline Oxalic acid & - & - \\
\hline Hippuric acid & - & - \\
\hline $\begin{array}{l}\text { Growth in the } \\
\text { presence of } \mathrm{NaCl}\end{array}$ & $\leq 5.0 \%$ & $\leq 5.0 \%$ \\
\hline Growth temp & $12-36^{\circ} \mathrm{C}$ & $12-38^{\circ} \mathrm{C}$ \\
\hline $\begin{array}{l}\text { Optimum temp for } \\
\text { growth }\end{array}$ & $26^{\circ} \mathrm{C}$ & $28^{\circ} \mathrm{C}$ \\
\hline \multicolumn{3}{|l|}{ Hydrolysis of: } \\
\hline Gelatin & + weak & - \\
\hline Starch & + & + \\
\hline Esculin & + & + \\
\hline Tween 20 & - & - \\
\hline Tween 40 & - & - \\
\hline Tween 60 & - & $\begin{array}{l}- \\
-\end{array}$ \\
\hline $\begin{array}{l}\text { 1ween } 80 \\
\text { Nitrate reduction }\end{array}$ & - & - \\
\hline Voges-Proskauer test & - & - \\
\hline Methyl red test & + & - \\
\hline Production of indole & - & - \\
\hline Production of $\mathrm{H}_{2} \mathrm{~S}$ & - & - \\
\hline Urease & - & - \\
\hline Oxidase & + & + \\
\hline Catalase & + & + \\
\hline $\begin{array}{l}\text { Oxidation- } \\
\text { fermentation test }\end{array}$ & Fermentation & Fermentation \\
\hline $\begin{array}{l}\text { Principal acid } \\
\text { metabolic product }\end{array}$ & Propionic acid & Propionic acid \\
\hline
\end{tabular}

teristics of both strains are summarized in Table 4. The amino acids in the cell wall were LL-DAP, alanine, glycine, and glutamic acid (molar ratio, ca. 1:2:1:1); this corresponds to the murein type A3 $\gamma$ of Schleifer and Kandler (32). Among cell wall sugars, arabinose and glucose were present but galactose 

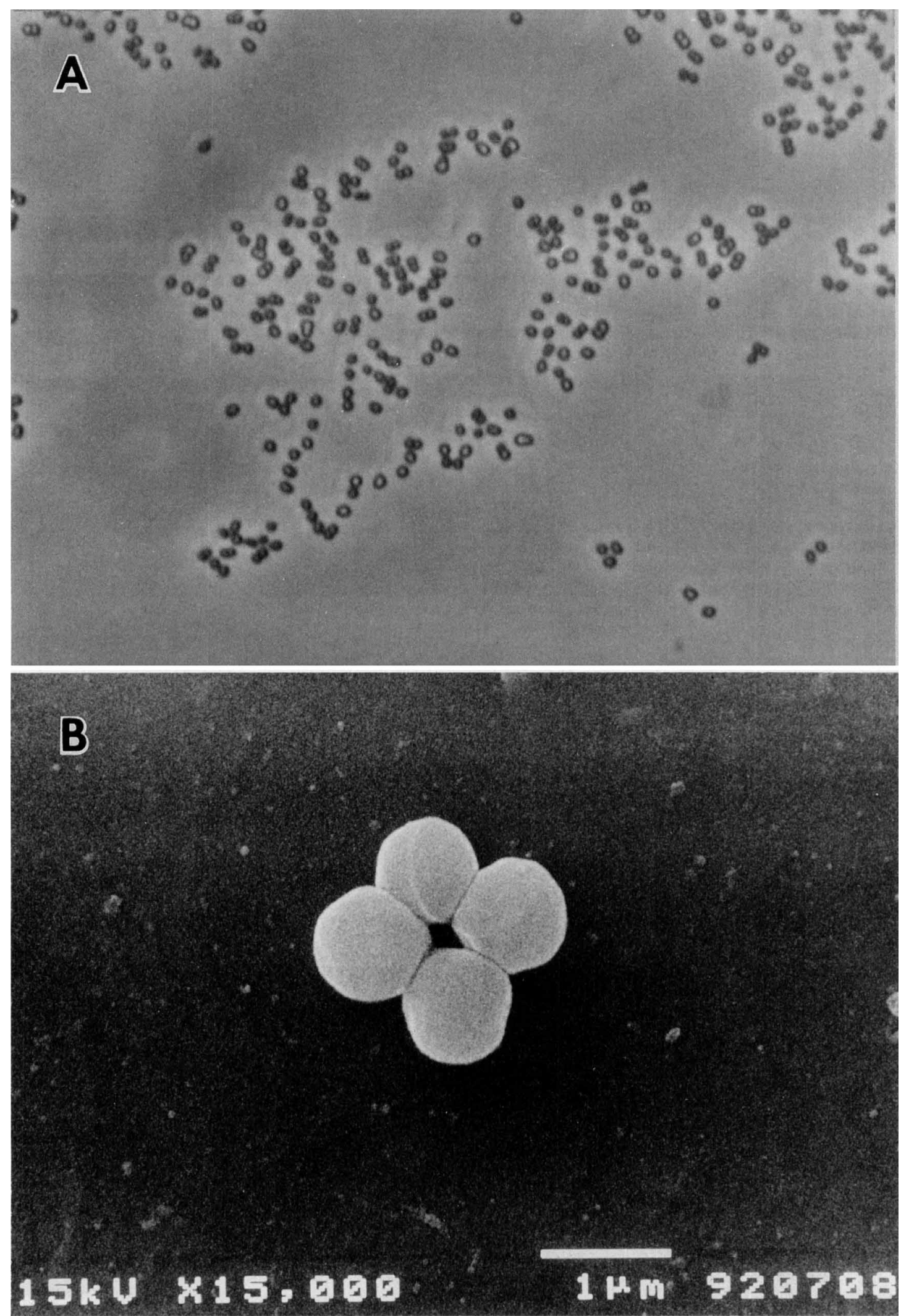

FIG. 1. Phase-contrast $(\mathrm{A})$ (magnification, $\times 800$ ) and scanning electron $(\mathrm{B})$ micrographs of cells of $L$. japonicus IFO $12422^{\prime}$ grown on yeast extract-malt extract agar. 

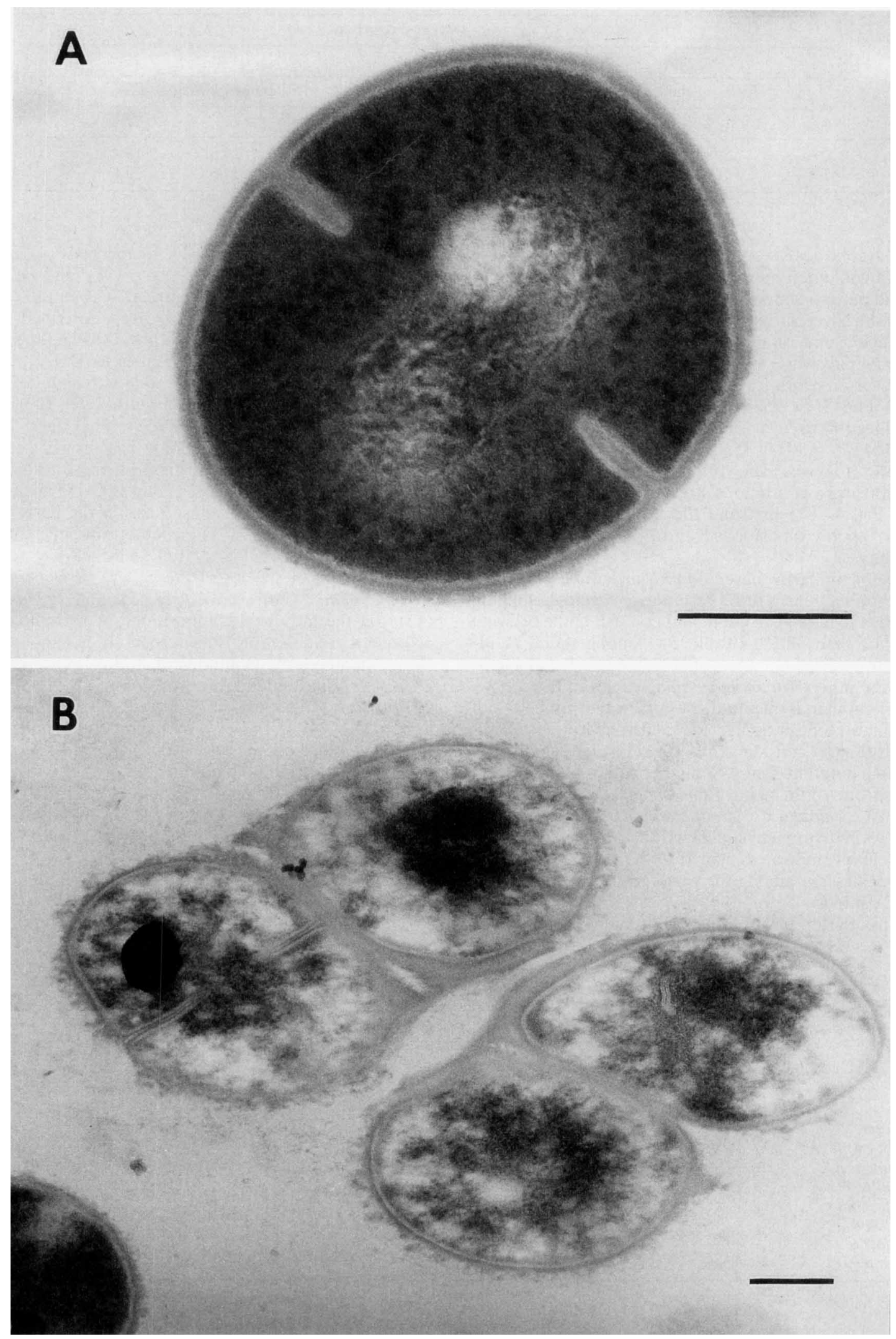

FIG. 2. Thin-section electron micrographs of L. japonicus IFO $12422^{\mathrm{T}}$. The cell division occurs alternately in two planes, the first division (A) and the second division $(\mathrm{B}) . \mathrm{Bar}=0.2 \mu \mathrm{m}$. 
TABLE 2. Cellular fatty acid compositions of the L. japonicus IFO $12422^{\mathrm{T}}$ and IFO 15385

\begin{tabular}{|c|c|c|c|c|c|c|c|c|c|}
\hline \multirow{4}{*}{ Strain } & \multicolumn{9}{|c|}{ Fatty acid composition (\%) } \\
\hline & \multicolumn{8}{|c|}{ Nonpolar } & \multirow{3}{*}{$\begin{array}{l}\text { 2-OH iso-Branched } \\
\quad \text { (iso- } \mathrm{C}_{18: 0} \text { ) }\end{array}$} \\
\hline & \multicolumn{4}{|c|}{ Saturated } & \multicolumn{4}{|c|}{ Unsaturated } & \\
\hline & $\mathrm{C}_{15: 0}$ & $\mathrm{C}_{16: 0}$ & $\mathrm{C}_{17: 0}$ & $C_{18: 0}$ & $\overrightarrow{C_{15: 1}}$ & $\mathrm{C}_{16: 1}$ & $\mathrm{C}_{17: 1}$ & $\mathrm{C}_{18: 1}$ & \\
\hline IFO $12422^{\mathrm{T}}$ & 2.6 & 5.0 & 3.1 & 1.8 & 5.0 & 35.6 & 29.6 & 15.4 & $\operatorname{tr}$ \\
\hline IFO 15385 & 1.1 & 7.2 & 1.5 & 1.5 & 2.2 & 59.5 & 12.5 & 12.1 & $\operatorname{tr}$ \\
\hline
\end{tabular}

was absent. Mycolic acids were not present. The glycan moiety of the murein contained only acetyl residues. The strains had the polar lipid pattern shown in Fig. 3. Diphosphatidylglycerol and phosphatidylglycerol were identified by their chromatographic behavior and staining characteristics. In addition, unknown glycolipids were present.

The DNA-DNA hybridization study revealed that strains IFO $12422^{\mathrm{T}}$ and IFO 15385 show very high DNA-DNA similarity values ( 90 to $99 \%$; data not shown), indicating that strains IFO $12422^{\mathrm{T}}$ and IFO 15385 belong to the same species.

Phylogenetic analysis. The $16 \mathrm{~S}$ rRNA sequence of IFO $12422^{\mathrm{T}}$, comprising a continuous stretch of 1,207 nucleotides, is shown in Fig. 4. The first and the last nucleotides in the sequence correspond to positions 8 and 1476 of the $E$. coli $16 \mathrm{~S}$ rRNA sequence (3).

The degree of similarity, based on 957 nucleotides, between IFO $12422^{\mathrm{T}}$ and sequences of representative species belonging to genera with a high $\mathrm{G}+\mathrm{C}$ content and LL-DAP in the cell wall was not higher than $93.5 \%$ (Table 5). Among them, $P$. innocuum was the closest neighbor of IFO $12422^{T}$. P. innocuum differs from the other Propionibacterium species in the following characteristics: it is facultatively anaerobic, its cell wall contains arabinose but not galactose, and it hydrolyzes starch (24). Therefore, we consider that $P$. innocuum should be transferred to a different genus. Similarity values between IFO $12422^{\mathbf{T}}$ and species of the genus Propionibacterium and species of the genus Nocardioides or Aeromicrobium are 91.1 to $93.5 \%$ and 91.4 to $93.2 \%$, respectively. Thus, the analysis of partial $16 \mathrm{~S}$ rRNA clearly indicates that IFO $12422^{\mathrm{T}}$ represents a distinct line of descent among the gram-positive bacteria with a high $\mathrm{G}+\mathrm{C}$ content.

Five genera of gram-positive cocci with high $\mathrm{G}+\mathrm{C}$ contents have been described previously: Micrococcus (4), Deinococcus (2), Stomatococcus (1), Kineococcus (38), and Pelczaria (25). However, no genera of cocci with LL-DAP in the cell wall and with a high $\mathrm{G}+\mathrm{C}$ content have been described. The genus Sarcina (31) is the only coccus with LL-DAP in the cell wall, and this genus has a low $\mathrm{G}+\mathrm{C}$ content in its DNA and is a strict anaerobe. Among gram-positive rods with high $\mathrm{G}+\mathrm{C}$ contents, the genera Nocardioides (26), Aeromicrobium (20), Terrabacter (5), Propionibacterium (23), Sporichthya (17), and Streptomyces (35) are known. Chemotaxonomy has proved very useful in finding characteristics that distinguish these taxa from neighboring taxa. Strains IFO $12422^{\mathrm{T}}$ and IFO 15385 can be readily distinguished from all of these taxa on the basis of chemical characteristics (Table 4). The chemotaxonomic characteristics of strains IFO $12422^{\mathrm{T}}$ and IFO 15385 closely resemble the characteristics of species of the genera of Nocardioides (16), Aeromicrobium (20), Terrabacter (5), and Propionibacterium (13), but the fatty acid composition and morphological characteristics are different. With respect to menaquinone composition, the major menaquinone of strains IFO $12422^{\mathrm{T}}$ and IFO $15385, N$. fastidiosa and $A$. erythreum is MK-9 $\left(\mathrm{H}_{4}\right)$, but that of $T$. tumescens and species of Nocardioides except for $N$. fastidiosa is $\mathrm{MK}-8\left(\mathrm{H}_{4}\right)$. The only menaquinone composition which has been reported for species of Propionibacterium is MK$9\left(\mathrm{H}_{4}\right)$. Thus, the combination of the presence of LL-DAP and a $\mathrm{G}+\mathrm{C}$ content of 66 to $68 \mathrm{~mol} \%$ and the presence of MK-9 $\left(\mathrm{H}_{4}\right)$ readily distinguishes strains IFO $12422^{\mathrm{T}}$ and IFO 15385 from all previously described gram-positive cocci with high $\mathrm{G}+\mathrm{C}$ contents (Table 4).

A comparative analysis of $16 \mathrm{~S}$ rRNA sequences suggests that the genus Micrococcus is more closely related to the genus Arthrobacter than to the other genera of gram-positive cocci

TABLE 3. Menaquinone compositions of IFO $12422^{\mathrm{T}}$, IFO 15385 , and related bacteria

\begin{tabular}{|c|c|c|c|c|c|c|c|c|}
\hline \multirow{2}{*}{ Strain or species } & \multicolumn{8}{|c|}{ Menaquinone composition $^{a}$} \\
\hline & $\mathrm{MK}-7\left(\mathrm{H}_{4}\right)$ & MK-8 & MK- $8\left(\mathrm{H}_{2}\right)$ & $\mathrm{MK}-8\left(\mathrm{H}_{4}\right)$ & $\mathrm{MK}-8\left(\mathrm{H}_{6}\right)$ & MK-9 $\left(\mathrm{H}_{4}\right)$ & $\mathrm{MK}-9\left(\mathrm{H}_{6}\right)$ & MK-9 $\left(\mathrm{H}_{8}\right)$ \\
\hline IFO $12422^{\mathrm{T}}$ & & & - & - & - & +++ & $\operatorname{tr}$ & $\operatorname{tr}$ \\
\hline IFO 15385 & & & - & - & - & +++ & $\operatorname{tr}$ & $\operatorname{tr}$ \\
\hline Propionibacterium $^{b}$ & & & & & & +++ & & \\
\hline Aeromicrobium erythreum ${ }^{c}$ & + & & & + & & +++ & & \\
\hline Terrabacter tumescens ${ }^{d}$ & + & & & +++ & + & $\operatorname{tr}$ & & \\
\hline Nocardioides albus ${ }^{e}$ & + & - & + & +++ & + & $\operatorname{tr}$ & & \\
\hline Nocardioides fastidios $\alpha^{f}$ & & & & + & & +++ & + & \\
\hline Nocardioides jensenii ${ }^{g}$ & & & & +++ & & & & \\
\hline Nocardioides luteus ${ }^{e}$ & + & - & + & +++ & + & $\operatorname{tr}$ & & \\
\hline Nocardioides simplex ${ }^{d}$ & + & + & - & +++ & + & $\operatorname{tr}$ & & \\
\hline
\end{tabular}

${ }^{a}+$, presence; - , absence.

${ }^{b}$ Data from reference 13 .

${ }^{c}$ Originally reported as lacking menaquinone (20).

${ }^{d}$ Data from reference 6.

${ }^{c}$ Data from reference 7.

${ }^{f}$ Data from reference 8.

${ }^{g}$ Data from reference 22 . 


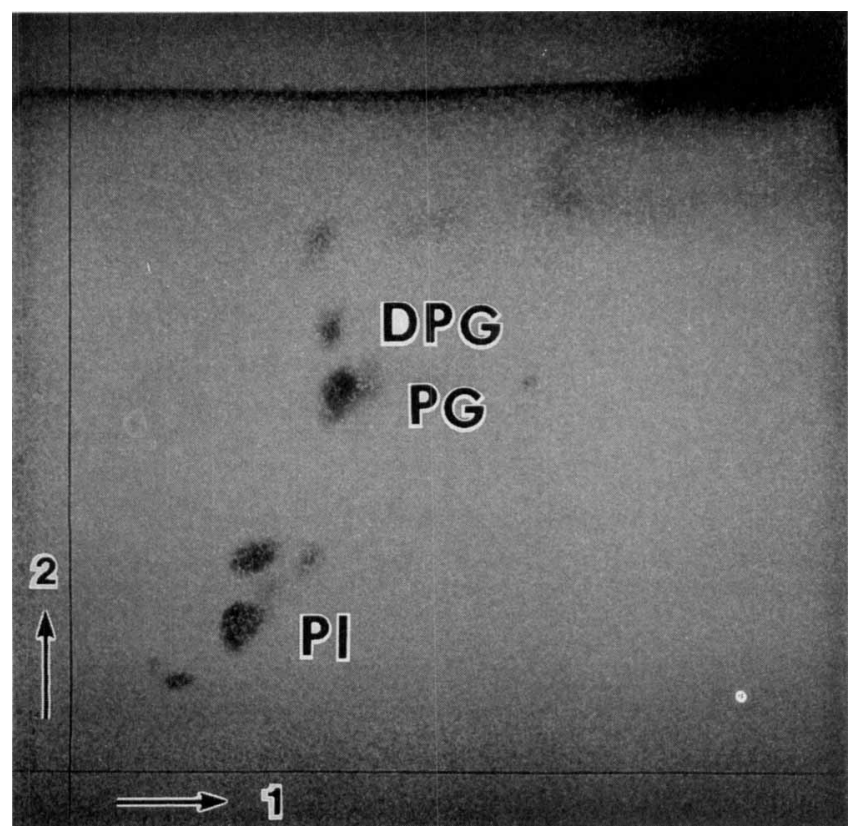

FIG. 3. Two-dimensional thin-layer chromatogram of the polar lipids of $L$. japonicus IFO $12422^{\mathrm{T}}$. Chloroform-methanol-water (65: $25: 4, \mathrm{vol} / \mathrm{vol} / \mathrm{vol}$ ) was used in the first dimension, and chloroformmethanol-acetic acid-water $(80: 12: 18: 5, \mathrm{vol} / \mathrm{vol} / \mathrm{vol} / \mathrm{vol})$ was used in the second dimension. Lipids were visualized by spraying the plates with $10 \%$ molybdophosphoric acid in ethanol, before heating them at $150^{\circ} \mathrm{C}$ for $10 \mathrm{~min}$. Abbreviations: DPG, diphosphatidylglycerol; PG, phosphatidylglycerol; PI, phosphatidylinositol.

$(20,33)$. Comparative analysis also indicates a similar relationship between the genera Deinococcus and Thermus (36). These genera form a phylum distinct from the phylum of grampositive bacteria (37). In this study, the coccoid form IFO $12422^{\mathrm{T}}$ was revealed to be phylogenetically more closely related to rod-shaped $P$. innocuum than to the other genera of gram-positive cocci, rods, and nocardioforms with high $\mathrm{G}+\mathrm{C}$ content (Fig. 5).

Thus, on the basis of biochemical and chemical criteria and phylogenetic analysis, strains IFO $12422^{\mathrm{T}}$ and IFO 15385 can be readily distinguished from all previously described grampositive cocci and in our opinion warrant a new taxon. Therefore, we formally propose that strains IFO $12422^{\mathrm{T}}$ and IFO

AGAGTTTGATCCTGGCTCAGGACGAACGCTGGCGGCGTGCTTAACACATGCAAGTCGAAC GGTAAGCGGTGTTGAAACTCCGTGGTATTGGATGGCCTCGCGGCCTATCAGCTTGTTGGT GAGGTAGTGGCTCACCAAGGCTTCGACGGGTAGCCGGCCTGAGAGGGCGACCGGCCACAC TGGGACTGAGATACGGCCCTCTACGGGAGGCAGCAGTGGGGAATATTGCACAATGGGCGA AGACTGATGCAGCAACGCCGCGTGCGGGATGACGGCCTTCGGGTTTTAAACCGCTTTCAA CGCAGACGAAGCGAAAGTGACGGTATGCGTAGAAGAAGCACCGGCAACTAGTITAA GGTGCGAGCGTTGTCCGGAATTATTGGGTTA GAATCATCA GAATAAATCACAGAG TIAGGGGACGGATTCCTGGTGGACGTGATAGGCTTAGATACCCTTGTAGTCCACGC CGTAAACGGTGGGTACTAGGTGTGGGTTACATTCCACGTGATCCGTGCCGCATATAACGC ATTAAGTACCCGCCTGGGGAGTACGGGCGCAAGGCTAAAACTCAAAGGAATTGACGGGGG CCCGCACAAGCGGCGGAGCATGCGGATTAATTCGATGCAACGCGAAGAACCTTACCTGGG TTTGACATATGCCGGAAACATTCAGAGATGGATGTTCACTTTTTGGTCCGGTATACAGGT GGTGCATGGCTGTCGTCAGCTCGTGTCGTGAGATGTTGGGTTAAGTCCCGCAACAGCGCA ACCCTTTCCTTTGTTGCCAGCACGTAATGGTGGGAACTCAAAGGAGACTGCCGGTGTCAA ATCGGAGGAAGGTGGGGATGACGTCAAGTCATCATGCCCCTTATGTCCAGGGCTTCACGC ATGCTACAATGGCCGGTACAAAGGGCTGCGAACCTGTAAGGGTGAGCTAATCCCAAAAAG CCGGTCTATTCGTATACAAAGGCTGCGAACCTOCA TCGCICTCATCGATIA TCGAAATCAACGCTGCGGTGAATACGTTCCCGGGCCTTGTACACACCGCCCGTCAA GTCACGAGAGTAGGTAACACCCGAAGCCGGTGGCCCAACCGTGAGGAGGGAGCTGTCGAA
GGTGGGA

FIG. 4. Partial $16 \mathrm{~S}$ rRNA sequence of $L$. japonicus IFO $12422^{\mathrm{T}}$. N, undetermined nucleotide.

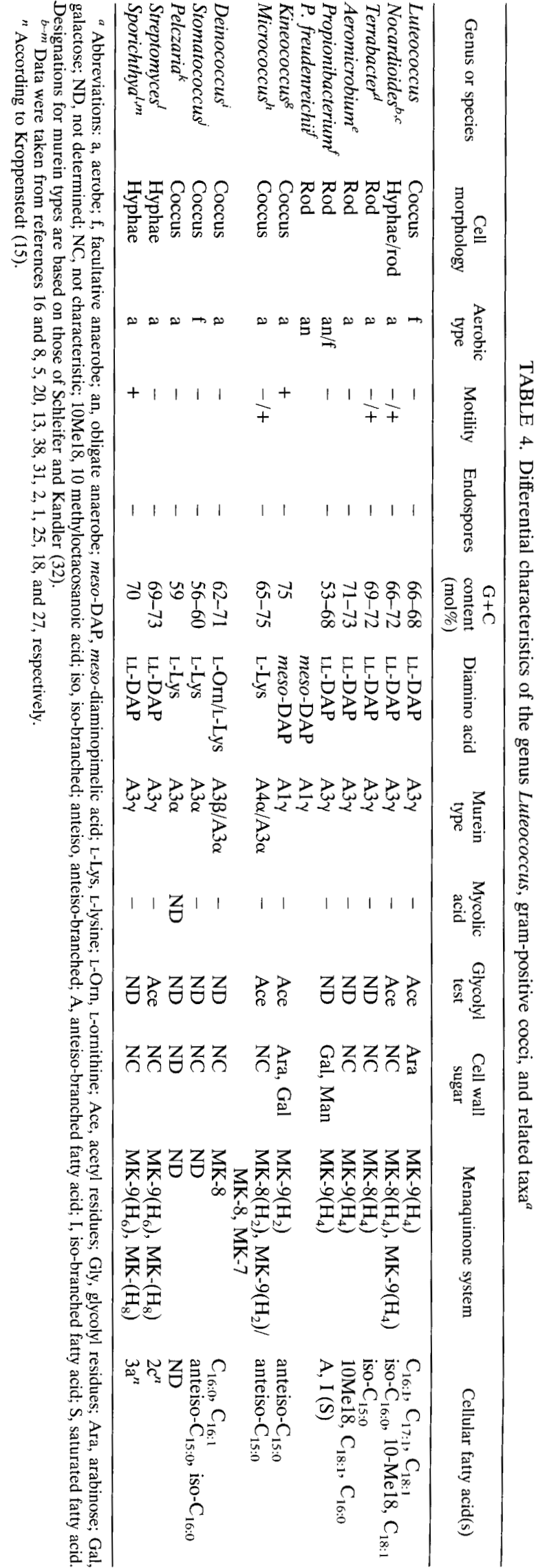




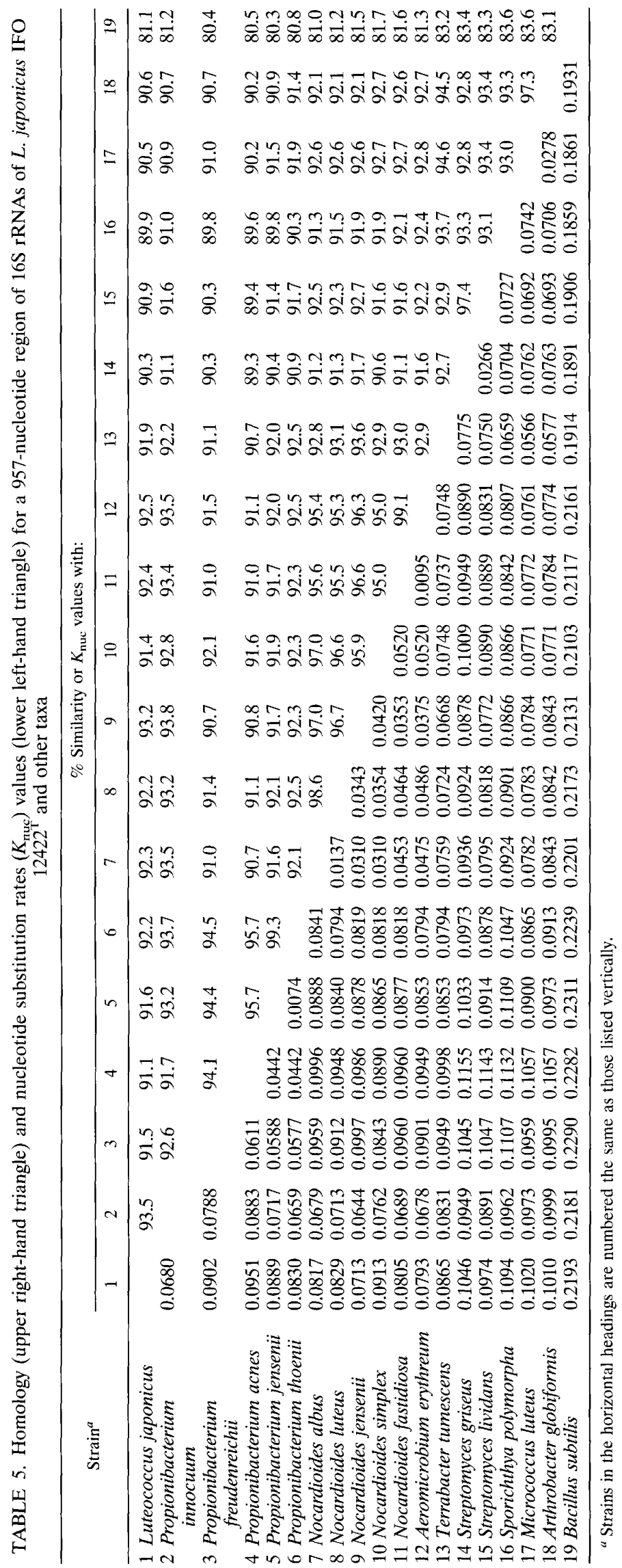




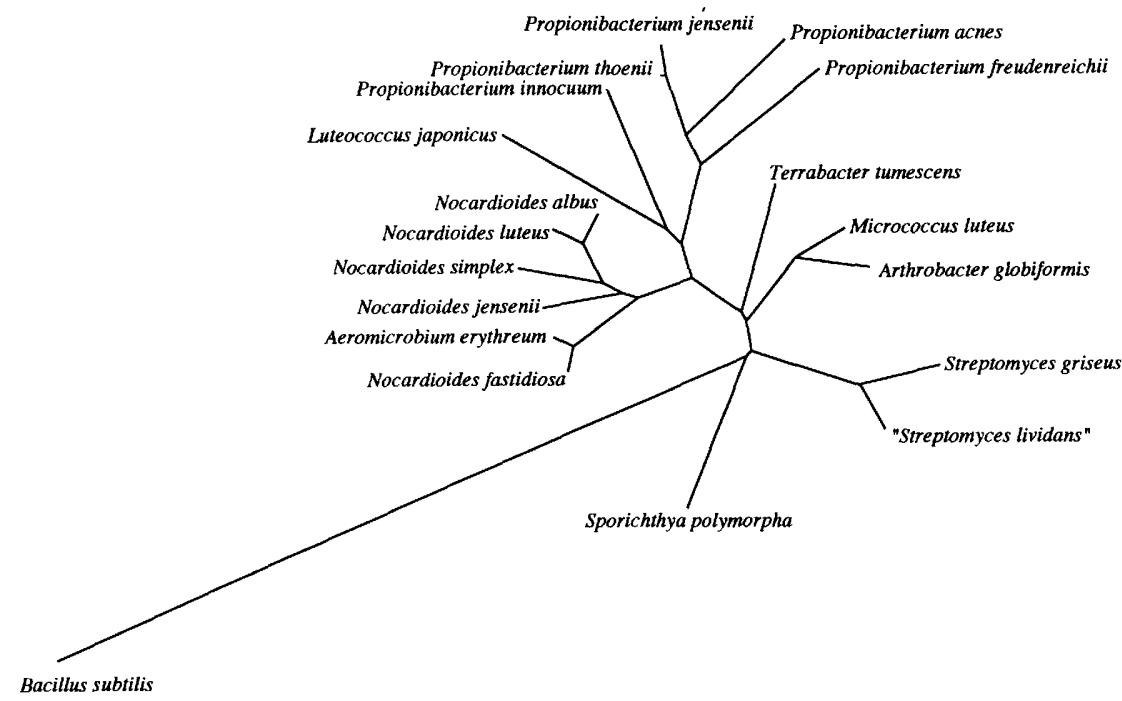

FIG. 5. Unrooted phylogenetic tree displaying the position of L. japonicus with regard to some other actinomycete taxa. The tree is based on a comparison of 957 bases.

15385 be classified in a new genus, Luteococcus, as Luteococcus japonicus gen. nov., sp. nov.

Descriptions for the new genus and new species are given below.

Description of Luteococcus gen. nov. Luteococcus (Lu.te.o.coc'cus. Lat. adj. luteus yellow; Gr. masc. n. coccus a grain; M.L. masc. n. Luteococcus yellow coccus). Cells are spherical and 0.7 to $1.0 \mu \mathrm{m}$ in diameter and occur singly, in pairs, or in tetrads. Endospores are not formed. Gram-positive. Colonies are circular and smooth and may be cream colored to yellow. Facultatively anaerobic. Catalase and oxidase positive. Urease negative. The cells do not reduce nitrate to nitrite. Starch is hydrolyzed. Tween $20,40,60$, and 80 are not hydrolyzed. Acid is produced from glucose and some other sugars. Propionic acid is formed from glucose as a major product. Optimum growth temperature is 26 to $28^{\circ} \mathrm{C}$.

Cell wall peptidoglycan contains LL-diaminopimelic acid, alanine, glycine, and glutamic acid (ca. 1:2:1:1). The major menaquinone is MK-9( $\left.\mathrm{H}_{4}\right)$. Mycolic acid is not present. The major cellular fatty acid is $16: 1$, and among the minor components a small amount of $2-\mathrm{OH}$ iso-18:0 is also present. Arabinose is present as a diagnostic sugar in the cell wall. As polar lipids, phosphatidylinositol, diphosphatidylglycerol, and phosphatidylglycerol are present.

Type species is Luteococcus japonicus.

Description of Luteococcus japonicus sp. nov. Luteococcus japonicus (ja.po'ni.cus. M.L. masc. adj. japonicus, pertaining to Japan, where the organisms were isolated) cells are spherical and 0.7 to $1.0 \mu \mathrm{m}$ in diameter and occur singly, in pairs, or in tetrads. Endospores are not formed. Gram-positive. Facultatively anaerobic. Colonies are circular and smooth and may be cream colored to yellow. Catalase and oxidase positive. Urease negative. The cells do not reduce nitrate to nitrite. Oxidationfermentation is fermentative. Acid is produced from D-glucose, D-ribose, D-galactose, D-mannose, D-fructose, sucrose, maltose, trehalose, raffinose, glycerol, mannitol, inositol and L-arabinose but not from D-xylose, D-arabinose, or L-rhamnose. Propionic acid is produced from glucose. Starch is hydrolyzed. Gelatin is weakly or not hydrolyzed. Optimum growth temperature is 26 to $28^{\circ} \mathrm{C}$.

Chemical characteristics such as amino acid composition of cell wall peptidoglycan, menaquinone system, mycolic acids, cellular fatty acids, and polar lipids are the same as those described for the genus. The DNA base composition of the type strain is 67 mol\% as determined by HPLC. Distribution: soil, water.

The type strain is IFO 12422.

\section{ACKNOWLEDGMENTS}

We thank Isamu Miura, Drug Safety Research Laboratories, Takeda Chemical Ind. Ltd., for expert electron microscopy and Zdena Pacova, Czech Collection of Microorganisms (CCM), for providing a bacterial strain.

This research was supported by grant 03304017 from Grant-in-Aid for Co-operative Research, the Ministry of Education, Science and Culture of Japan.

\section{REFERENCES}

1. Bergan, T., and M. Kocur. 1982. Stomatococcus mucilaginosus gen. nov., sp. nov., sp. rev., a member of the family Micrococcaceae. Int. J. Syst. Bacteriol. 32:374-377.

2. Brooks, B. W., and R. G. E. Murray. 1981. Nomenclature for "Micrococcus radiodurans" and other radiation-resistant cocci: Deinococcaceae fam. nov. and Deinococcus gen. nov., including five species. Int. J. Syst. Bacteriol. 31:353-360.

3. Brosius, J., J. L. Palmer, J. P. Kennedy, and H. F. Noller. 1978. Complete nucleotide sequence of a 16S ribosomal RNA gene from Escherichia coli. Proc. Natl. Acad. Sci. USA 75:4801-4805.

4. Cohn, F. 1872. Untersuchungen über Bakterien. Beitr. Biol. Pflanz. 1(Heft):127-224.

5. Collins, M. D., M. Dorsch, and E. Stackebrandt. 1989. Transfer of Pimelobacter tumescens to Terrabacter gen. nov. as Terrabacter tumescens comb. nov. and of Pimelobacter jensenii to Nocardioides as Nocardioides jensenii comb. nov. Int. J. Syst. Bacteriol. 39:1-6.

6. Collins, M. D., M. Goodfellow, and D. M. Minnikin. 1979. Isoprenoid quinone in the classification of coryneform and related bacteria. J. Gen. Microbiol. 110:127-136.

7. Collins, M. D., R. M. Keddie, and R. M. Kroppenstedt. 1983. Lipid composition of Arthrobacter simplex, Arthrobacter tumescens and possibly related taxa. Syst. Appl. Microbiol. 4:18-26.

8. Collins, M. D., and E. Stackebrandt. 1989. Molecular taxonomic studies on some LL-diaminopimelic acid-containing coryneforms from herbage: description of Nocardioides fastidiosa sp. nov. FEMS Microbiol. Lett. 57:289-294.

9. Cowan, S. T., and K. J. Steel. 1965. Manual for the identification 
of medical bacteria. Cambridge University Press, London.

10. Ezaki, T., Y. Hashimoto, and E. Yabuuchi. 1989. Fluorometric deoxyribonucleic acid-deoxyribonucleic acid hybridization in microdilution wells as an alternative to membrane filter hybridization in which radioisotopes are used to determine genetic relatedness among bacterial strains. Int. J. Syst. Bacteriol. 39:224-229.

11. Higgins, D. R., A. J. Bleasby, and R. Fuchs. 1992. Clustal V: improved software for multiple sequence alignment. Comput. Appl. Biosci. 8:189-190.

12. Ina, Y. 1991. Molecular evolutionary analysis system for DNA and amino acid sequences (ODEN), version 1.1. DNA Data Bank of Japan (DDBJ), DNA Research Center, National Institute of Genetics, Mishima, Japan.

13. Jones, D., and M. D. Collins. 1986. Section 15. Irregular, nonsporing Gram-positive rods, p. 1261-1434. In P. H. A. Sneath, N. S. Mair, M. E. Sharpe, and J. G. Holt (ed.), Bergey's manual of systematic bacteriology, vol. 2. The Williams \& Wilkins Co., Baltimore.

14. Kimura, M. 1980. A simple method for estimating evolutionary rates of base substitutions through comparative studies of nucleotide sequences. J. Mol. Evol. 16:111-120.

15. Kroppenstedt, R. M. 1985. Fatty acid and menaquinone analysis of actinomycetes and related organisms, p. 173-199. In M. Goodfellow and D. E. Minnikin (ed.), Chemical methods in bacterial systematics. Academic Press, Ltd., London.

16. Lechevalier, H. A. 1986. Section 26. Nocardioform actinomycetes, p. 2348-2404. In P. H. A. Sneath, N. S. Mair, M. E. Sharpe, and J. G. Holt (ed.), Bergey's manual of systematic bacteriology, vol. 4. The Williams \& Wilkins Co., Baltimore.

17. Lechevalier, M. P., H. A. Lechevalier, and P. E. Holbert. 1968. Sporichthya, un nouveau genre de Streptomycetaceae. Ann. Inst. Pasteur (Paris) 114:277-286.

18. Locci, R. 1986. Section 29. Streptomycetes and related genera, $p$ 2451-2508. In P. H. A. Sneath, N. S. Mair, M. E. Sharpe, and J. G. Holt (ed.), Bergey's manual of systematic bacteriology, vol. 4. The Williams \& Wilkins Co., Baltimore.

19. Mesbah, M., U. Premachandran, and W. B. Whitman. 1989. Precise measurement of the $\mathrm{G}+\mathrm{C}$ content of deoxyribonucleic acid by high-performance liquid chromatography. Int. J. Syst. Bacteriol. 39:159-167.

20. Miller, E. S., C. R. Woese, and S. Brenner. 1991. Description of the erythromycin-producing bacterium Arthrobacter sp. strain NRRL B-3381 as Aeromicrobium erythreum gen. nov., sp. nov. Int. J. Syst. Bacteriol. 41:363-368.

21. Oda, M. 1935. Bacteriological studies on water used for brewing sake (part 6). 1. Bacteriological studies on "miyamizu." Micrococcus and Actinomyces isolated from "miyamizu." Jozogaku Zasshi 13:1202-1228. (In Japanese.)

22. O'Donnell, A. G., M. Goodfellow, and D. E. Minnikin. 1982. Lipids in the classification of Nocardioides: reclassification of Arthrobacter simplex (Jensen) Lochhead in the genus Nocardioides (Prauser) emend. O'Donnell et al. as Nocardioides simplex comb. nov. Arch. Microbiol. 133:323-329.
23. Orla-Jensen, S. 1909. Die Hauptlinien des natürlichen Bakteriensystems. Zentralbl. Bakteriol. Parasitenkd. Infektionskr. Hyg. Abt. II. 22:305-346.

24. Pitcher, D. G., and M. D. Collins. 1991. Phylogenetic analysis of some LL-diaminopimelic acid-containing coryneform bacteria from human skin: description of Propionibacterium innocuum sp. nov. FEMS Microbiol. Lett. 84:295-300.

25. Poston, J. M. 1993. Pelczaria aurantia gen. nov., sp. nov., a newly described orange-colored bacterium. Arch. Microbiol. 160:114120 .

26. Prauser, H. 1976. Nocardioides, a new genus of the order Actinomycetales. Int. J. Syst. Bacteriol. 26:58-65.

27. Rainey, F. A., P. Schumann, H. Prauser, R. Toalster, and E. Stackebrandt. 1993. Sporichthya polymorpha represents a novel line of descent within the order Actinomycetales. FEMS Microbiol. Lett. 109:263-268.

28. Saiki, R. K., D. H. Gelfand, S. Stoffe, S. J. Scharf, R. Higuchi, G. T. Horn, K. B. Mullis, and A. Erlich. 1988. Primer-directed enzymatic amplification of DNA with a thermostable DNA polymerase. Science 239:487-491.

29. Saito, H., and K. Miura. 1963. Preparation of transforming deoxyribonucleic acid by phenol treatment. Biochim. Biophys. Acta 72:619-629.

30. Saitou, N., and M. Nei. 1987. The neighbor-joining method: a new method for reconstructing phylogenetic trees. Mol. Biol. Evol. 4:406-425.

31. Schleifer, K. H. 1986. Section 12. Gram-positive cocci, p. 9991103. In P. H. A. Sneath, N. S. Mair, M. E. Sharpe, and J. G. Holt (ed.), Bergey's manual of systematic bacteriology, vol. 2. The Williams \& Wilkins Co., Baltimore.

32. Schleifer, K. H., and O. Kandler. 1972. Peptidoglycan types of bacterial cell walls and their taxonomic implications. Bacteriol. Rev. 36:407-477.

33. Stackebrandt, E., and C. R. Woese. 1979. A phylogenetic dissection of the Family Micrococcaceae. Curr. Microbiol. 2:317-322.

34. Takeuchi, M., F. Kawai, Y. Shimada, and A. Yokota. 1993 Taxonomic study of polyethylene glycol-utilizing bacteria: emended description of the genus Sphingomonas and new description of Sphingomonas macrogoltabidus sp. nov., Sphingomonas sanguis sp. nov. and Sphingomonas terrae sp. nov. Syst. Appl. Microbiol. 16:227-238.

35. Waksman, S. A., and A. T. Henrici. 1943. The nomenclature and classification of the actinomycetes. J. Bacteriol. 46:337-341.

36. Weisburg, W. G., S. J. Giovannoni, and C. R. Woese. 1989. The Deinococcus-Thermus and the effect of rRNA composition on phylogenetic tree construction. Syst. Appl. Microbiol. 11:128-134.

37. Woese, C. R. 1987. Bacterial evolution. Microbiol. Rev. 51:221271.

38. Yokota, A., T. Tamura, T. Nishii, and T. Hasegawa. 1993. Kineococcus aurantiacus gen. nov., sp. nov., a new aerobic, grampositive, motile coccus with meso-diaminopimelic acid and arabinogalactan in the cell wall. Int. J. Syst. Bacteriol. 43:52-57. 